\title{
ANALISIS PERSEPSI PETANI PETERNAK SAPI POTONG TERHADAP PERAN PENYULUH DI KECAMATAN SANGKUB KABUPATEN BOLAANG MONGONDOW UTARA
}

\author{
Repli Talibo, B. F. J. Sondakh*, Adrie A. Sajow, Jolyanis Lainawa \\ Fakultas Peternakan Universitas Sam Ratulangi Manado, 95115
}

\begin{abstract}
ABSTRAK
Di kecamatan Sangkub kabupaten Bolaang Mongondow utara terdapat 596 petani peternak sapi potong. Sebanyak 210 petani peternak diantaranya tergabung dalam 21 kelompok tani ternak. Dari 21 kelompok tani ternak tersebut terdapat tujuh kelompok yang masih tegolong aktif melaksanakan kegiatan usahanya, sedangkan kelompok lainnya tergolong tidak aktif. Kemugkinan hal ini disebabkan oleh manajemen dan modal dalam pelaksanaan kegiatan usaha ternak sapi potong yang masih buruk dan minim, serta pemahaman tentang nilai usaha ternak sapi potong yang kurang.Penelitian ini bertujuan untuk melihat bagaimana persepsi petani peternak sapi potong terhadap peran penyuluh di kecamatan Sangkub kabupaten Bolaang Mongondow Utara.

Jenis penelitian ini adalah penelitian deskriptif yaitu menggambarkan fenomena dari variabel penelitian. Pemilihan sampel kelompok tani ternak ditentukan secara sengaja (Purposive) yaitu kelompok tani ternak yang masih aktif dalam kegiatan usahanya yakni di desa Tomobolango Induk, Busisingo, dan Sangkub II. Pemilihan responden dilakukan dengan mengambil seluruh petani peternak pada sampel kelompok terpilih yang berjumlah 30 orang. Pengukuran variabel dilakukan dengan menerapkan Skala Likert yang pengukurannya diberi skor pada setiap indikator.
\end{abstract}

Hasil penelitian menunjukkan

\footnotetext{
*Korespondensi (corresponding author): Email : bfjsondakh@yahoo.com
}

bahwa persepsi petani peternak sapi potongterhadap peran penyuluh di kecamatan Sangkub kabupaten Bolaang Mongondow Utara jika ditinjau dari aspek peran penyuluh sebagai fasilitator, $96,67 \%$ menilai baik dan 3,33\% menilai sangat baik. Peran penyuluh sebagai mediator, 83,33\% menilai cukup baik dan 3,33\% menilai baik. Peran penyuluh sebagai motivator, $83,33 \%$ menilai baik dan $16,67 \%$ menilai sangat baik. Peran penyuluh sebagai edukator, 93,33\% menilai baik dan $6,67 \%$ menilai sangat baik. Peran penyuluh sebagai komunikator, $100 \%$ petani peternak menilai baik. Secara keseluruhan dapat disimpulkan bahwa persepsi petani peternak terhadap peran penyuluh di kecamatan Sangkub kabupaten Bolaang Mongondow Utara menunjukkan bahwa 93,33\% petani peternak menilai baik dan $6,67 \%$ menilai sangat baik.

Kata Kunci : Persepsi Petani Peternak, Peran Penyuluh

\section{ABSTRACT}

ANALYSIS OF CATTLE FARMERS PERCEPTION ON THE ROLE OF EXTENSION AGENTS IN SANGKUB DISTRICT NORTH OF BOLAANG MONGONDOW REGENCY. There are about 596 cattle farmers in Sangkub county North of Bolaang Mongondow Regency. Two hundreds and ten farmers from them are being corporated in 21 farmer groups. From those twenty one farmers, seven farmer groups that are actively categorized in farming operation, while others are considered inactive anymore. The reason for that might be due to the lack of capital or farm management 
misconduct, or the lack of knowledge in the value of cattle farming. The present study was designed to elaborate the perception of cattle farmers on the role of extension agents in Sangkub County North ofBolaang Mongondow Regency.

The research was conducted in a descriptive method that delineated phenomenon of research variables. Cattle farmers group samples were choosen purposely and finally farmers in the village of Tombolango Induk, Busisingo, and Sangkub II were included in the study. All of thirty cattle farmers were taken as samples. Variables measurement were conducted using 'Likert Scale' and scoring at each indicator.

Research results showed that perception of cattle farmers on the role of extension agents in Sangkub County North of Bolaang Mongondow Regency can be rated as follow: in term of extension agents as facilitator: $96.67 \%$ good, $3.33 \%$ very good; extension agents as mediator: $83.33 \%$ good enough (fair), $3.33 \%$ good; extension egents as motivator: $83.33 \%$ good enough (fair), $16.67 \%$ very good; extension agents as educator: $93.33 \%$ good, $6.67 \%$ very good; extension agents as communicator: $100 \%$ good. Overall, it can be concluded that perception of cattle farmers on the role of extension agents in Sangkub County of Bolaang Mongondow Utara Regency rated $93.33 \%$ as good and $6.67 \%$ as very good.

Keywords: Perception,Cattle Farmers, Extension Agents, Bolaang Mogondow Utara Regency

\section{PENDAHULUAN}

\section{Latar Belakang}

Dalam proses pemberdayaan petani peternak diperlukan adanya penyuluh yang mampu menghubungkan ilmu pengetahuan kepetani peternak melalui kegiatan penyuluhan yang bertujuan untuk merubah perilaku petani peternak agar lebih tahu, mau, dan mampu dalam menjalankan kegiatan usahanya. Namun demikian, persepsi petani peternak terhadap peran seorang penyuluh juga sangat menentukan dalam pengambilan keputusan dalam adopsi inovasi sehingga dapat terjadinya perubahan perilaku dari petani peternak itu sendiri. Hal ini sesuai dengan penelitian Saswita et al (2013), bahwa persepsi peternak tentang peranan penyuluh dalam meningkatkan pengetahuan dan manajemen peternakan sapi berhubungan positif nyata dengan manajemen peternakan sapi. Hal tersebut menunjukkan peranan penyuluh mempengaruhi tingkat penerapan manajemen. Dengan demikian semakin berperan penyuluh tersebut maka semakin mampu peternak melaksanakan manajemen dalam beternak sapi.

Berdasarkan data Badan Pusat Satistik daerah Kecamatan Sangkub dalam angka 2016 bahwa di kecamatan ini terdapat 596 petani peternak sapi potong. Menurut data BP3K Kecamatan Sangkub (2016),sebanyak 210 petani peternak diantaranya tergabung dalam 21 kelompok tani ternak. Dari 21kelompok tani tersebut terdapat tujuh kelompok yang masih tegolong aktif melaksanakan kegiatan usahanya, sedangkan kelompok lainnya tergolong tidak aktif. Kemugkinan hal ini disebabkan oleh buruknya manajemen dalam pelaksanaan kegiatan usaha ternak 
sapi potong, modal yang minim, serta pemahaman tentang nilai usaha ternak sapi potong yang kurang.Hal ini senada dengan pendapat Timbulus et al (2016), yang mengemukakan bahwa persepsi yang terbentuk dalam diri petani akan mempengaruhi cara pandangnya terhadap manfaat dan keunggulan peran penyuluh. Persepsi petani terhadap keunggulan peran penyuluh dapat menjadi salah satu faktor penghambat atau pendorong bagi petani dalam pengembangan petani.

Berdasarkan hal-hal tersebut maka dilakukan penelitian tentang persepsi petani peternak terhadap peran penyuluh yang ditinjau dari segi perannyasebagai fasilitator, mediator, komunikator, motivator, dan edukator.Adapun tujuan dari penelitian ini adalah untuk menganalisis persepsi petani peternak sapi potong terhadap peran penyuluh di Kecamatan Sangkub Kabupaten Bolaang Mongondow Utara.

\section{METODE PENELITIAN}

\section{Tempat dan waktu}

Penelitian ini dilaksanakan di Kecamatan Sangkub Kabupaten Bolaang Mongondow Utara, yaitu di desaTombolango, Busisingo Induk, dan Sangkub II pada tanggal 20 Desember 2016 sampai 20 Januari 2017.

\section{Populasi dan sampel}

Populasi dalam penelitian ini adalah seluruh petani peternak sapi potong yang tergabung dalam 21 kelompok tani ternak yang berjumlah 210 peternak.

Pemilihan sampel kelompok tani ternak ditentukan secara sengaja (Purposive), maka sampel dari penelitian ini yaitu kelompok tani ternak Keong Mas di desa Tombolango, kelompok tani ternak Motumping Mandiri di desa Busisingo Induk, dan kelompok tani ternak Kwi Bersehati di desa Sangkub IIyang juga memiliki masing-masing 10 anggota petani peternak. Pemilihan responden dilakukan dengan mengambil seluruh petani peternak pada sampel kelompok terpilih yang berjumlah 30 orang.

\section{Jenis dan sumber data}

Jenis data dalam penelitian ini berupa data kualitatif. Sumber data meliputi data primer dan data sekunder. Data primer diperoleh melalui wawancara dengan petani peternak sapi potong.Data sekunder diperoleh dari kantor Dinas Pertanian Kabupaten Bolaang Mongondow Utara, Balai Penyuluhan Pertanian, Perikanan, dan Kehutanan (BP3K) kecamatan Sangkub, serta Badan Pusat Statistik Kabupaten Bolaang Mongondow Utara (Serial online). 


\section{Metode pengumpulan data}

Metode yang digunakan adalah metode survey yaitu wawancara langsung dengan petani peternak sapi potong. Wawancara dilakukan dengan berpedoman pada daftar pertanyaan yang telah disiapkan dan disusun sesuai dengan tujuan penelitian.

\section{Definisi variabel dan pengukuran}

Variabel yang diukur dalam penelitian ini adalah persepsi petani peternak. Persepsi petani peternak merupakanproses psikologis petani peternak dalam pengambilan keputusan untuk menghasilkan gambaran mengenai kenyataan yang berbeda dengan kenyataan yang ada. Dalam hal ini yaitu meliputi persepsi petani peternak sapi potong terhadap peran penyuluh sebagai fasilitator, mediator, komunikator, motivator, dan edukator.

$$
\text { Pengukuran persepsi petani }
$$

peternak sapi potong terhadap peran penyuluh dilakukan denganmenjabarkan terlebih dahulu terhadap variabel yang diukur. Variabel dijabarkan menjadi indikator yang kemudian digunakan sebagai dasar dalam penyusunan kuesioner penelitian.Pengukuran indikator dilakukan dengan menerapkan skala likert yang pengukurannya diberi skor pada setiap indikator. Skor dinyatakan dalam bilangan bulat $(1,2,3,4,5)$. Respon sangat baik diberikan skor 5, sebaliknya respon tidak baik diberikan skor 1 .

\section{Metode analisis data}

Analisis data mengenai persepsi petani peternak sapi potong terhadap peran penyuluhmenggunakan model Interval Kelas (Dajan, 1986).Model Interval kelas yang digunakan adalah sebagai berikut:

$$
\mathrm{I}=\frac{\text { Skor maksimal }- \text { Skor minimal }}{\text { Banyaknya kategori }}
$$

Keterangan:

I = Interval kelas

\section{HASIL DAN PEMBAHASAN}

\section{Peran penyuluh sebagai fasilitator}

$$
\text { Berdasarkan kegiatan penelitian }
$$
yang dilakukan mengenai persepsi peternak terhadap peran penyuluh sebagai fasilitator dalam memfasilitasi kegiatan pembelajaran peternak sapi potong Dikecamatan Sangkub Kabupaten Bolaang Mongondow Utara, maka didapatkan hasil analisisyang disajikan dalam tabel 1 berikut. 
Tabel 1. Distribusi responden menurut persepsi terhadap peran penyuluh sebagai fasilitator

\begin{tabular}{cccc}
\hline Sub variable & Kategori & Jumlah peternak & Persentase (\%) \\
\hline & Sangat baik & 1 & 3,33 \\
Peran penyuluh & Baik & 29 & 96,67 \\
sebagai fasilitator & Cukup baik & - & - \\
& Kurang baik & - & - \\
& Tidak baik & - & - \\
\hline & & $\mathbf{3 0}$ & $\mathbf{1 0 0}$ \\
\hline
\end{tabular}

Berdasarkan tabel 1 diatas bahwa persepsi peternak sapi potong terhadap peran penyuluh dari segi peran sebagai fasilitator menunjukkan bahwa sebagianbesar atau 29 responden menyatakan baik. Hal ini menunjukkan bahwa penyuluh dilokasi penelitian sudah baik dalam mengidentifikasi dan menyelesaikan permasalahan yang dihadapi peternak.Selain ituperan penyuluh dalam memfasilitasi pengadaan alat dan mesin yang digunakan,serta memfasilitasi proses diskusi pada pertemuan kelompok peternak jugasudah sangat baik.Secara keseluruhan peran penyuluh sebagai fasilitator dinilai oleh peternak adalah sebesar $3,33 \%$ peternak menilai sangat baik dan $96,67 \%$ menilai baik.

Tabel 2. Distribusi responden menurut persepsi terhadap peran penyuluh sebagai mediator

\begin{tabular}{cccc}
\hline Sub variable & Kategori & Jumlah peternak & Persentase (\%) \\
\hline & Sangat baik & - & - \\
Peran penyuluh sebagai & Baik & 5 & 16,67 \\
mediator & Cukup baik & 25 & 83,33 \\
& Kurang baik & - & - \\
& Tidak baik & - & - \\
\hline & & $\mathbf{3 0}$ & $\mathbf{1 0 0}$ \\
\hline
\end{tabular}

\section{Peran penyuluh sebagai mediator}

Peniliaian persepsi peternak terhadap peran penyuluh sebagai mediator yang diukur dalam penelitian ini adalah peran penyuluh dalam menjembatani bimbingan teknis dengan pemerintah, menjembatani penyelesaian konflik dengan pihak luar, keterampilan penyuluh dalam mengelola konflik, kreatifitas penyuluh dalam berkomunikasi dan menganalisis pemecahan masalah, kemampuan mengontrol marah dan emosi dalam penyelesaian masalah, serta pelayanan penyuluh dalam membantu mengumpulkan berbagai masalah dalam kelompok. Adapun hasil penilaian tersebut disajikan pada tabel 2 berikut ini. 
Tabel 2 menunjukkan bahwa sebagian besar atau 25 responden menyatakan cukup baik. Jika ditinjau dari indikator yang diukur, maka hasil analisis juga menunjukkan bahwa peran penyuluh sebagai mediator berada dalam kategori cukup baik.Secara keseluruhan penilaian petani peternak terhadap peran penyuluh adalah sebesar $16,67 \%$ peternak menilai baik dan 83,33\% menilai cukup baik.

\section{Peran penyuluh sebagai motivator}

Penilaian peran penyuluh sebagai motivator berdasarkan persepsi peternak dilokasi penelitian menunjukkan bahwa persepsi peternak terhadap peran penyuluh sebagai motivator sebagian besar $(83,33 \%)$ berada pada kategori baik. Berdasarkan indikator yang diukur, peran penyuluh menunjukkan bahwa kemampuan penyuluh dalam memberikan semangat untuk meningkatkan kepercayaan diri anggota kelompok agar terlibat aktif dalam kegiatan kelompok dalam kategori sangat baik. Selain itu peran penyuluh yang juga berada pada kategori sangat baik yaitu dalam hal memotivasi anggota kelompok untuk meningkatkan kemampuan melaksanakan kegiatan usaha serta mencapai hasil yang diinginkan. Sedangkan indikator yang berada dalam kategori baik yaitu profesional penyuluh dalam mempraktekkan apa yang disuluhkan, serta keterlibatan penyuluh dalam memberikan solusi pengembangan usaha. Secara keseluruhan peran penyuluh sebagai motivator dinilai oleh peternak adalah sebesar $16,67 \%$ peternak menilai sangat baik dan $83,33 \%$ menilai baik. Adapun data mengenai persepsi petani peternak terhadap peran penyuluh sebagai motivator disajikan dalam table 3 berikut.

Tabel 3. Distribusi responden menurut persepsi terhadap peran penyuluh sebagai motivator

\begin{tabular}{cccc}
\hline Sub variabel & Kategori & Jumlah peternak & Persentase (\%) \\
\hline & Sangat baik & 5 & 16,67 \\
$\begin{array}{c}\text { Peran penyuluh } \\
\text { sebagai motivator }\end{array}$ & Baik & 25 & 83,33 \\
& Kurang baik & - & - \\
& Tidak baik & - & - \\
\hline & & - & $\mathbf{1 0 0}$
\end{tabular}


Peran penyuluh sebagai edukator

Berdasarkan hasil analisis mengenai persepsi peternak terhadap peran penyuluh sebagai edukator, maka didapatkan bahwa hasil analaisis persepsi peternak terhadap peran penyuluh sebagai edukator sebagian besar atau 28 responden menilai baik. Dilihat dari indikator yang diukur dalam penelitian ini, hasil yang berada pada kategori sangat baik yaitu peran penyuluh dalam membimbing dan melatih peternak dalam keterampilan teknis, serta peran penyuluh dalam memberikan berbagai informasi pengetahuan teknis mencakup teknologi yang dibutuhkan peternak. Sedangkan indikator yang berada dalam kategori baik yaitu kemampuan penyuluh dalam meningkatkan pengetahuan dan keterampilan peternak dalam mengidentifikasi masalah, pengetahuan penyuluh dalam membekali kelompok agar terjadi perubahan perilaku anggota kelompok, serta cara penyuluh dalam memberikan masukan tentang teknologi yang belum tentu sesuai dengan kondisi dilapangan. Selain itu terdapat indikator yang masih berada pada kategori cukup yaitu tentang kesesuaian proses pelaksanaan penyuluhan yang dilaksanakan. Secara keseluruhan peran penyuluh sebagai edukator dinilai oleh peternak adalah sebesar $6,67 \%$ peternak menilai sangat baik dan $93,33 \%$ menilai baik. Data selengkapnya mengenai persepsi petani peternak terhadap peran penyuluh sebagai educator disajikan dalam Tabel 3 berikut.

Tabel 4. Distribusi responden menurut persepsi terhadap peran penyuluh sebagai edukator

Sub variable
Kategori

Sangat baik

Baik
Jumlah peternak

Persentase (\%)

\begin{tabular}{cccc}
\hline & Sangat baik & 2 & 6,67 \\
& Baik & 28 & 93,33 \\
$\begin{array}{c}\text { Peran penyuluh } \\
\text { sebagai educator }\end{array}$ & Cukup baik & - & - \\
& Kurang baik & - & - \\
& Tidak baik & - & - \\
\hline
\end{tabular}


Peran penyuluh sebagai komunikator

Hasil analisis mengenai persepsi peternak terhadap peran penyuluh sebagai komunikator bahwa dinilai oleh 30 responden berada pada kategori baik. Ditinjau dari indikator yang diukur, maka hasil penelitian menunjukkan bahwa indikator yang berada dalam kategori sangat baik yaitu cara penyuluh memberikan informasi yang disampaikan agar mudah dimengerti peternak dan dan memberikan informasi teknologi secara langsung tatap muka. Sedangkan indikator yang berada pada kategori baik yaitu mengenai pemberian informasi dan teknologi menggunakan media audio visual dan media berupa obyek fisik atau benda nyata. Namun demikian, juga terdapat indikator yang masih berada pada kategori cukup yaitu tentang kemampuan penyuluh memposisikan diri sebagai bagian dari kelompok ketika berdiskusi dengan peternak serta pemberian informasi teknologi menggunakan media cetak. Secara keseluruhan peran penyuluh sebagai komunikator dinilai oleh $100 \%$ peternak tergolong baik. Data selengkapnya mengenai persepsi petani peternak terhadap peran penyuluh sebagai komunikator disajikan dalam tabel 5 berikut.

Tabel 5. Distribusi responden menurut persepsi terhadap peran penyuluh sebagai komunikator
Sub variable
Kategori
Jumlah peternak
Persentase $(\%)$

Sangat baik

Baik

30

100

Peran penyuluh sebagai komunikator

Cukup baik

Kurang baik

Tidak baik 
Rekapitulasi hasil analisis persepsi
peternak terhadap peran penyuluh

Berdasarkan hasil analisis persepsi peternak terhadap peran penyuluh pada masing-masing sub indikator penilaian yaitu peran penyuluh sebagai fasilitator, mediator, motivator, edukator, dan komunikator yang disajikan dalam table 6, maka di dapatkan hasil yang menunjukkan bahwa secara keseluruhan nilai persepsi peternak sapi potong terhadap peran penyuluh di Kecamatan Sangkub Kabupaten Bolaang Mongondow Utara, yang paling menonjol yaitu sebagai komunikator dengan persentase $100 \%$. Berdasarkan persentase nilai persepsi petani peternak terhadap keseluruhan aspek peran penyuluh menunjukkan bahwa, dua responden menilai sangat baik dan 28 responden lainnya menilai baik. Secara umum penilaian petani peternak terhadap peran penyuluh memiliki persentase yang berbeda-beda. Ada yang terbagi dalam kategori sangat baik dan baik, ada juga yang terbagi dalam kategori baik dan cukup baik.

Adanya perbedaan persepsi petani peternak tersebut dapat disebabkan oleh karakteristik individu dari masing-masing petani peternak seperti umur, tingkat pendidikan, dan pengalaman beternak. Semakin baik karakteristik peternak, maka akan semakin baik pula persepsi terhadap fenomena yang diterima. Hal tersebut didukung oleh hasil penelitian Muhammad et al (2014), yang menyatakan bahwa terdapat hubungan yang sangat nyata antara lama usaha dengan persepsi peternak, serta terdapat hubungan yang nyata antara umur dan tingkat pendidikan dengan persepsi peternak.

Tabel 6. Rekapitulasi nilai persepsi peternak terhadap peran penyuluh

\begin{tabular}{llccccc}
\hline & & \multicolumn{5}{c}{ Kategori nilai } \\
\cline { 3 - 7 } No & Aspek peran penyuluh & $\begin{array}{c}\text { Sangat } \\
\text { baik }\end{array}$ & Baik & $\begin{array}{c}\text { Cukup } \\
\text { baik }\end{array}$ & $\begin{array}{c}\text { Kurang } \\
\text { baik }\end{array}$ & $\begin{array}{c}\text { Tidak } \\
\text { baik }\end{array}$ \\
\cline { 3 - 7 } & & $(\%)$ & $(\%)$ & $(\%)$ & $(\%)$ & $(\%)$ \\
\hline 1 & Sebagai fasilitator & 3,33 & 96,67 & - & - & - \\
2 & Sebagai mediator & - & 16,67 & 83,33 & - & - \\
3 & Sebagai motivator & 16,67 & 83,33 & - & - & - \\
4 & Sebagai edukator & 6,67 & 93,33 & - & - & - \\
5 & Sebagai komunikator & - & 100 & - & - & - \\
\hline
\end{tabular}


Melihat hal ini bahwa persepsi petani peternak terhadap peran penyuluh sudah menujukkan persepsi yang baik yakni persepsi terhadap peran penyuluh sebagai fasilitator, motivator, edukator, dan komunikator. Namun demikian terdapat penilaian peran penyuluh yang masih tergolong cukup baik yaitu perannya sebagai mediator dengan persentase $83,33 \%$, dimana hal ini menunjukkan bahwa sebagai mediator dalam menjembatani bimbingan teknis, penyelesaian konflik, mengelola konflik, menganalisis pemecahan masalah, mengontrol emosi dalam penyelesaian masalah, dan mengumpulkan berbagai masalah dalam kelompok belum optimal.

Melihat persepsi peternak terhadap peran penyuluh sebagai mediator masih dalam kategori cukup baik, maka hal ini dapat disebabkan oleh keterbatasan pengetahuan dan keterampilan penyuluh dalam mengaplikasikan ilmu pengetahuan yang ada, sehingga masalah-masalah yang terjadi dalam kegiatan usaha ternak sapi potong belum sepenuhnya diatasi oleh petani peternak. Persepsi peternak ini dapat berpengaruh terhadap tingkat partisipasi, semakin baik persepsi peternak, maka semakin baik pula tingkat partisipasi peternak dalam kegiatan penyuluhan. Persepsi dan partisipasi yang paling penting diperhatikan dan diharapkan menurut Baba et al (2011), adalah persepsi terhadap materi yang sesuai dengan kebutuhan peternak, metode yang memberi kesempatan kepada peternak untuk berpartisipasi, serta kemampuan fungsional penyuluh yang dapat menyelesaikan permasalahan yang dihadapi peternak dan partisipasi dalam pelaksanaan dan pemanfaatan hasil penyuluhan.

Menurut Indraningsih (2011), bahwa tingkat persepsi petani peternak terhadap manfaat penyuluhan dapat ditingkatkan melalui kegiatan penyuluhan yang intensif, yang semula tergolong baik (kategori sedang) menjadi lebih baik (kategori tinggi). Berdasarkan hal tersebut maka salah satu yang dibutuhkan yaitu adanya penguatan kelembagaan kelompok yang di dampingi oleh penyuluh, dalam ini adalah kelompok tani ternak sapi potong yang ada di Kecamatan Sangkub Kabupaten Bolaang Mongondow Utara yang merupakan sasaran utama dan secara tidak langsung merasakan manfaat dari pelakasanaan kegiatan penyuluhan. Sehubungan dengan hal tersebut,Priyono et al (2015), dalam penelitiannya menyatakan bahwa kontribusi tingkat teknologi, dukungan kelembagaan, dan peran penyuluh pertanian secara simultan memiliki pengaruh yang nyata terhadap tingkat adopsi oleh petani peternak. Dukungan kelembagaan memiliki hubungan yang cukup erat, positif, dan 
nyata dengan peran penyuluh pertanian sehingga sinergi antara penyuluh dan kelembagaan petani diperlukan dalam meningkatkan transfer teknologi pada petani.

Tingkat persepsi peternak terhadap peran penyuluh dapat berpengaruh terhadap perubahan perilakunya. Sebaliknya perilaku tidak dapat dilepaskan dari persepsi peternak tersebut terhadap tindakan yang dilakukannya. Dalam hal ini bahwa persepsi merupakan proses pengambilan keputusan peternaktentang kenyataan yang berbeda dengan kenyataan yang ada. Hal ini sesuai dengan apa yang dikemukakan oleh Baba et al (2011), yang menyatakan bahwa persepsi terhadap pelaksanaan penyuluhan yang tinggi mampu meningkatkan partisipasi peternak dalam penyuluhan dan tingkat partisipasi peternak dalam penyuluhan yang tinggi mampu meningkatkan kinerja usaha peternak. Peternak yang memiliki tingkat partisipasi tinggi mampu meningkatkan adopsi teknologi.

Menurut Saridewi dan Siregar (2010), bahwa adopsi teknologi oleh petani lebih berpengaruh terhadap peningkatan produksi dibandingkan dengan peran penyuluh. Hal ini berarti bahwa dalam pelaksanaan kegiatan penyuluhan harus benar-benar melihat sampai sejauh mana tingkat adopsi oleh petani. Jika petani belum sampai pada tahap menerapkan, maka program peningkatan produksi jangan dulu dijalankan, agar hasil yang diperoleh lebih baik. Abdullah (2008), menyatakan bahwa untuk meningkatkan adopsi teknologi peternakan dalam pengembangan sapi potong, beberapa kriteria yang perlu dipertimbangkan terkait dengan teknologi introdusir ke peternak. Teknologi harus dirasakan sebagai kebutuhan oleh peternak kebanyakan, memberi keuntungan mendayagunakan sumberdaya yang ada, terjangkau oleh finansial peternak, serta teknologi harus sederhana, tidak rumit, dan mudah dicoba oleh peternak.

\section{KESIMPULAN}

Berdasarkan hasil analisis persepsi petani peternak sapi potong pada 30 responden yang ada di Kecamatan Sangkub Kabupaten Bolaang Mongondow Utara, maka dapat disimpulkan sebagai berikut :

1. Secara parsial persepsi petani peternak terhadap peran penyuluh ditinjau dari aspek peran penyuluh sebagai fasilitator, 96,67\% menilai baik dan 3,33\% menilai sangat baik. Peran penyuluh sebagai mediator, $83,33 \%$ menilai cukup baik dan 3,33\% menilai baik. Peran penyuluh sebagai motivator, $83,33 \%$ menilai baik dan $16,67 \%$ menilai sangat baik. Peran 
penyuluh sebagai edukator, $93,33 \%$

menilai baik dan $6,67 \%$ menilai sangat baik. Peran penyuluh sebagai komunikator, $100 \%$ petani peternak menilai baik.

2. Secara keseluruhan persepsi petani peternak sapi potong terhadap peran penyuluh menunjukkan hasil yang bervariasi, sebagian besar baik $(93,33 \%)$ dan sebagian kecil sangat baik $(6,67 \%)$.

\section{DAFTAR PUSTAKA}

Abdullah, A. 2008. Peranan Penyuluhan dan Kelompok Tani Ternak untuk Meningkatkan Adopsi Teknologi dalam Peternakan Sapi Potong. Jurnal Prosiding Seminar Nasional Sapi Potong. Fakultas Peternakan Unhas Makassar, Sulawesi Selatan.:188-195.

BP3K Kecamatan Sangkub. 2016. FormKelompok Tani Ternak. BP3K.

Badan Pusat Statistik Kabupaten Bolaang Mongondow Utara. 2016. Kecamatan Sangkub dalam Angka 2016 : Badan Pusat Statistik. (Serial Online) 23 April 2017. https://bolmongkab.bps.go.id/new/ba ckend/pdf_publikasi/

Kecamatan-Sangkub-dalam-Angka2016.pdf

Baba, S., Isbandi, T. Mardikanto, dan Waridin. 2011. Pengaruh Persepsi dan Tingkat Partisipasidalam Penyuluhan terhadap Kinerja UsahaPeternak Sapi Perah di Kabupaten Enrekang. Seminar Nasional Teknologi Peternakan dan Veteriner. Universitas Diponegoro Semarang. :208-216.
Dajan, A. 1986. Pengantar Metode Statistik Jilid II. Jakarta: LP3ES.

Indraningsih, K. S. 2011. Pengaruh Penyuluhan terhadap Keputusan Petani dalam Adopsi Inovasi Teknologi Usahatani Terpadu. Jurnal Agro Ekonomi. 29 (1) :1-24.

Muhammad, S. D. S., R. A. J. Legrans, E. Wantasen, dan J. Lainawa. 2014. Hubungan antara Faktor Sosial Ekonomi dengan Persepsi Peternak terhadap Pengembangan Usaha Peternakan Sapi Perah di Kota Tomohon. Jurnal Zootek. 34 (2) : 39-49.

Priyono, M. I. Shiddieqy, D. Widiyantono, Dan Zulfanita. 2015. Hubungan Kausal antara Tingkat Penguasaan Teknologi, DukunganKelembagaan, dan Peran Penyuluh Terhadap Adopsi IntegrasiTernak-Tanaman. Jurnal Informatika Pertanian.24 (2) : 141-148.

Saridewi, T. R. dan A. R. Siregar. 2010. Hubungan Antara Peran Penyuluh dan Adopsi Teknologi Oleh Petani Terhadap Peningkatan Produksi Padi di Kabupaten Tasikmalaya. Jurnal Penyuluhan Pertanian. 5 (1) : 55-61.

Saswita, I. M. U., I. N. Suparta, dan I. G. Suarta. 2013. Persepsi Peternak Tentang Peranan Penyuluh Dalam Meningkatkan Pengetahuan Dan Manajemen Peternakan Sapi Di Kelompok Ternak Sapi Sekar Sari Desa Pangsan, Kecamatan Petang, Badung. E-Jurnal Peternakan Tropika. 1 (1) :34-44.

Timbulus, M. V. G., M. L. Sondakh, G. A. J. Rumagit. 2016. Persepsi Petani Terhadap Peran Penyuluh Pertanian di Desa Rasi Kecamatan Ratahan Kabupaten Minahasa Tenggara. Jurnal Agri-Sosioekonomi Unsrat. 12(2A) : 19-40. 